\title{
The Trans-Pacific Partnership Agreement (TPPA) Minus 1: What's Next for Malaysian Small and Medium Enterprises (SMEs)?
}

\author{
Charlie Albert Lasuin ${ }^{1^{\star}}$ \\ Azizah Omar ${ }^{2}$ \\ T. Ramayah ${ }^{2}$ \\ ${ }^{1}$ Faculty of Business, Economics and Accountancy, \\ Universiti Malaysia Sabah, Sabah, Malaysia \\ ${ }^{2}$ School of Management, Universiti Sains Malaysia, \\ Penang, Malaysia \\ ${ }^{*}$ Corresponding Author
}

Doi: 10.2478/mjss-2018-0091

\begin{abstract}
TPPA faced turbulence and uncertainty among its members when the newly-elected President of the United States, Mr. Donald Trumps abandoned the trade deal. Now, the so-called TPP11 or TPP 12 minus one becomes talk of the town especially to the remaining countries with hopes that the trade deal can be salvage and turn into a reality. Malaysia has another option to rely on in case the trade deal faced the dead end. This paper discuss the possible steps and mitigations for Malaysia and also local SMEs in dealing with the future of TPP11 with the alternative economic deal such as Asean Economic Community (AEC) and Regional Comprehensive Economic Partnership (RCEP). Local SMEs can enhance their products and services by focusing on domestic market as well as looking for opportunity in the international market as another way to survive in the red ocean market. The introduction of the Digital Free Trade Zone (DFTZ) creates another opportunity for Malaysian SMEs to optimise the emerging growth of the Internet economy and cross border e-commerce activities. In addition, the DFTZ would enhanced local SMEs in terms of export capabilities in the digital market particularly with China. Local SMEs should remain proactive, resilience and versatile in facing the world's economic uncertainty particularly the TPP for the sustainability of their business livelihood. Thus, this paper will review the next step for Malaysian SMEs in dealing with the uncertain future of the TPPA minus 1.
\end{abstract}

Keywords: TPPA, Domestic Market, Market Opportunity, Mitigation, Trade Liberalisation, SMEs, Malaysia

\section{Introduction}

President Trump formally pull out the US from the TPPA on January 23 after sworn in as the 45th US president on January 2017 (Bradner, 2017; Chua, 2017). His decision came as predictable as he criticised against the international trade deals for causing the employment and industrial difficulties in the US as a signature theme of his campaign (Garcia, 2017; Smith, 2017). At the same time, Trump also announced that he will renegotiate the terms under North American Free Trade Agreement (NAFTA) with Canada and Mexico in order to come up with a better deal for US (Bradner, 2017; Chua, 2017; Garcia, 2017; Savransky, 2017; Smith, 2017) (Figure 1). The TPP was previously negotiated by former President Barack Obama during his administration (Diamond \& Bash, 2017). The trade pact came with ambitious and comprehensive free regional trade deal that would tie the relationship and joint market penetration between US with 11 Pacific Rim nations 
namely Australia, Brunei, Canada, Chile, Japan, Malaysia, Mexico, New Zealand, Singapore, Peru and Vietnam (Figure 1). These countries accounts for around 40 per cent of world economy or the gross domestic product (GDP) (Al Jazeera, 2017; Palit, 2017). Obama had argued that this deal would provide an effective geopolitical counterweight to China in the region particularly in the Pacific Rim (Greenfield \& White, 2017; Petrosyan et al., 2017; Smith, 2017).

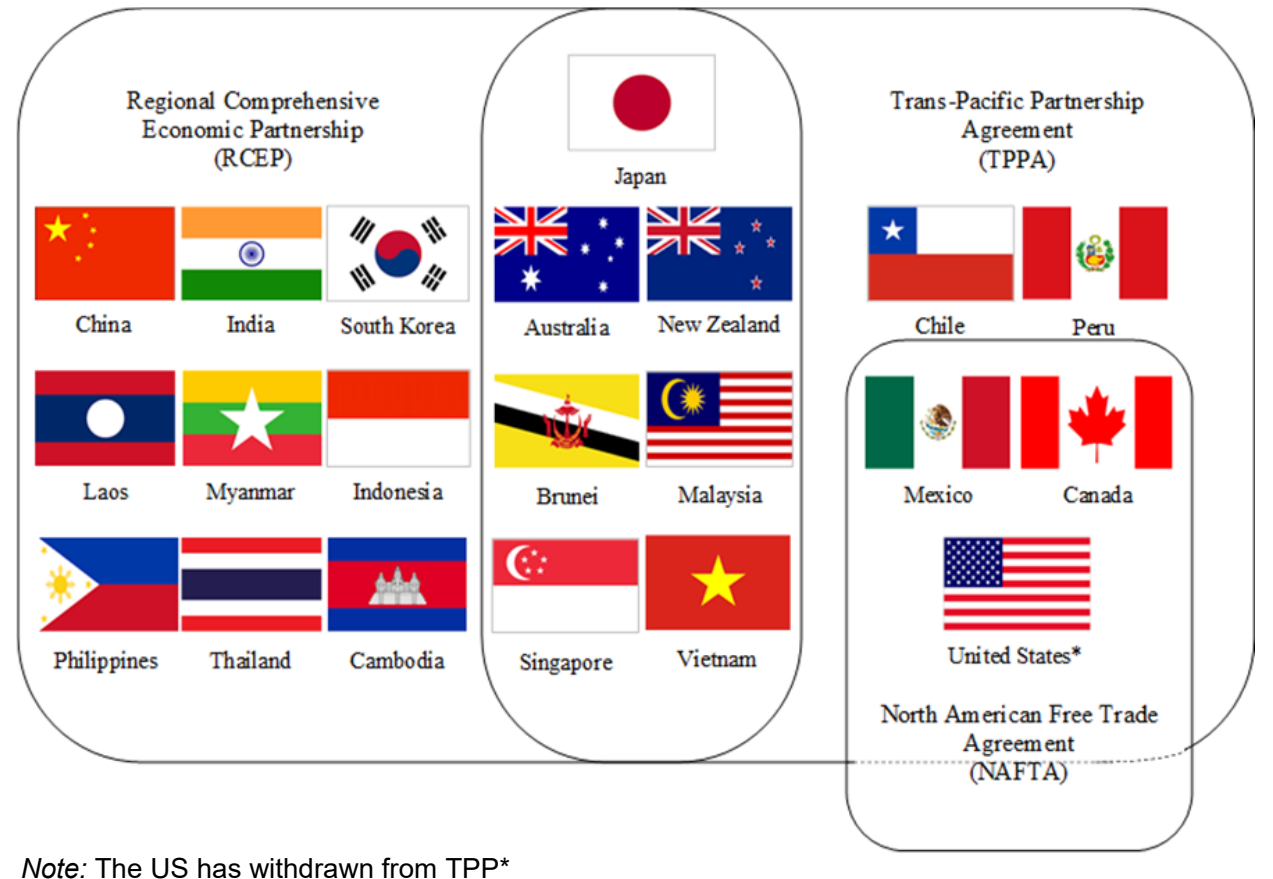

Figure 1: Countries Participations in RCEP, TPPA and NAFTA

Source: CNN Research in Jozuka, 2017

According to Northam (2016), TPP is an agreement that focused on the elimination of tariffs and assist in setting the rigid standard for copyright protections as well as the intellectual property rights. In addition, the deal also aimed on upholding the economic development, innovation, efficiency and competitiveness (Harun, 2017). The agreement's rules also stated a minimum of six countries accounting for 85 per cent of the combined GDP of the 12 members must ratify before the TPP can come into force and ironically, the US economy accounts for nearly 60 per cent of the member's GDP (Agencies, 2016; Nguyen, 2017; Zulfakar, 2016). However, the agreement has neither submitted for ratification nor approved by US Republican-controlled Congress and had nevertheless to go into effect (Al Jazeera, 2017; Olorunnipa et al., 2017; Smith, 2017; Walters, 2017). Trump's action on abandoning TPP which was initiated by his predecessor showed his aggressive movement towards foreign rivals in promoting his slogan "America First" (Baker, 2017). After the series of meetings, 19 rounds of negotiations and hard work among the members including Malaysia, finally the TPPA surfaced as the so-called TPP11 or TPP 12 minus one after the US left the agreement (Rana \& Ji, 2017). Therefore, it is timely to discuss the possible consequences faced by the participating members particularly to the Malaysian SMEs in mitigating with the situation. This paper is to review the next step for Malaysian SMEs in dealing with the uncertain future of the TPPA minus 1 based from the analysis of secondary data. 


\section{SMEs in Malaysia}

SMEs becomes the backbone for economic development and major contributor to country's gross domestic product (GDP) of both developed as well as developing countries (Hashim \& Ahmad, 2006; Suntivong, 2010). According to Mutandwa et al. (2015), SMEs are being considered as an alternative to conventional industrialisation due to rise in population and unemployment in several parts of the world. The words small and medium enterprises or SMEs are larger than life without any universally accepted definition. However, there are various criteria use to portray SMEs with different nations practise various measure of size based from their level of development (Mgeni, 2015). The Indonesian SMEs are defined based on asset and annual sales turnover while in Myanmar, the capital outlay, production value and power usage defines their SMEs Asian Development Bank, 2014; Central Department of Small and Medium Enterprises Development, 2015). Further, Malaysian SMEs are defined based on annual sales turnover and number of employees (Table 1).

Table 1: Definition of SMEs in Malaysia based on Annual Sales Turnover and Number of Full-Time Employees (Effective 1 January, 2014)

\begin{tabular}{|c|c|c|c|}
\hline & Size and Criteria & Annual Sales Turnover & $\begin{array}{c}\text { Number of Full-Time } \\
\text { Employees }\end{array}$ \\
\hline Micro & $\frac{\text { Manufacturing }}{\text { Services \& Other Sectors }}$ & Not exceeding RM300,000 & Not exceeding 5 employees \\
\hline \multirow{2}{*}{ Small } & Manufacturing & $\begin{array}{l}\text { Sales turnover from RM300,000 } \\
\text { to less than RM15 million }\end{array}$ & $\begin{array}{l}\text { Full-time employees from } 5 \\
\text { to less than } 75\end{array}$ \\
\hline & Services \& Other Sectors & $\begin{array}{l}\text { Sales turnover from RM300,000 } \\
\text { to less than RM3 million }\end{array}$ & $\begin{array}{l}\text { Full-time employees from } 5 \\
\text { to less than } 30\end{array}$ \\
\hline \multirow{2}{*}{ Medium } & Manufacturing & $\begin{array}{l}\text { Sales turnover from RM15 million } \\
\text { to not exceeding RM50 million }\end{array}$ & $\begin{array}{l}\text { Full-time employees from } 75 \\
\text { to not exceeding } 200\end{array}$ \\
\hline & Services \& Other Sectors & $\begin{array}{l}\text { Sales turnover from RM3 million } \\
\text { to not exceeding RM20 million or }\end{array}$ & $\begin{array}{l}\text { Full-time employees from } 30 \\
\text { to not exceeding } 75\end{array}$ \\
\hline
\end{tabular}

Notes: Manufacturing: Physical or chemical transformation of materials or components into new products. Services: Services including distributive trade; hotels and restaurants; business, professional and ICT services; private education and health; entertainment; financial inter-mediation; and manufacturing-related services such as research and development (R\&D), logistics, warehouse, engineering. Others: Primary agriculture, construction, mining \& quarrying.

\section{Source: SME Bank, 2017}

SMEs in Malaysia comes with a long journey of milestones since early 1960s (The Brand Laureate, 2017). Malaysian SMEs continuously contributes to the economic growth, source of employment and also transformation towards developed nation by 2020. Based from the SME Annual Report $2014 / 15$, there are a total of 645,136 SMEs in Malaysia which comprised of 496,458 for micro SMEs, while 128,787 and 19,891 are belongs to the small and medium-sized industry respectively. The services sector dominates SMEs with 90 per cent of business establishment, followed by followed by manufacturing (5.9\%) and construction (3.0\%) (SME Annual Report 2014/15). Malaysian Government has declared the year 2017 as the Startup and SME Promotion Year as a recognition for SMEs in contributing to the nation's development and employment market (Dali, 2016). According Kang (2016), a total of RM6.7 billion has been allocated for SMEs' development under Budget 2017 for its growth and sustainability. SME Corp. Malaysia stated that the local SMEs has sustained its growth between 37.3 and 37.5 per cent in 2016 regardless of the current economic challenges (The Brand Laureate, 2017). 


\section{What are the Next Step for Malaysia?}

\subsection{Revisit the Agreement}

According to Bhattacharjee (2017), the US withdrawal from the TPP offers an opportunity to Malaysia revisit and re-evaluate the balance of risks and benefits that arises with joining the so called mammoth trade agreement. This including the evaluation of the remains on the positive side of the deal against the downsides particularly on country's major export and its impacts on consumers, employees as well as small businesses (Bhattacharjee, 2017). Interestingly, Bhattacharjee (2017) also stated that the current situation of the TPP brings golden opportunity in designing new ways of to foster growth model with more humanity rather than merciless act of business. The US withdrawal from the TPP brought another positive side as it reduces its hegemony over other members in deciding the direction of TPPA (Bernama, 2017). This signify that the TPP members are freely to voice out their trade direction based on 30 Chapters embedded in the agreement.

The TPPA made the headlines in Malaysia and received numbers of criticism from all round the corner including the local politician (Lasuin et al., 2016). Many still viewed the TPP as a threat to their business particularly the SMEs (Bernama, 2017). This including the issues pertaining to the incentives promised in the agreement for local SMEs after joining the international market (Bernama, 2017). This is because the TPPA would create high competitiveness and domination threat by giant multinational as a result of market liberalisation (Bernama, 2017). In addition, the agreement also viewed as a creation of unfair competition between large companies and SMEs that could possibly ends the livelihood of SMEs due to their acts of survival in the global markets (Bernama, 2017).

\subsection{Time to Focus on Domestic Market}

According to Malaysia Retailer (2017), Malaysia GDP is expected to achieve 4.4 per cent in 2017 compared to 4.1 per cent in 2016. Similarly, the World Bank predicts Malaysia's economy will be improve slightly in 2017 to 2018 (Malaysia Retailer, 2017). Malaysian economy is also in recovering phase with the increasing of crude oil and palm oil prices, steady domestic economic and more understanding on the US economic policies (Kok, 2017; Rosli, 2017). In addition, consumer spending is expected to gradually recover and continue to grow in the second half of 2017 (Kana, 2017; Pooi, 2017). Foreign direct investment (FDI) for Malaysia also increased by 63.4 per cent with total investment of RM207.9 billion in 2016 (Fong, 2017).

Based from the report by PricewaterhouseCoopers (PwC), Malaysia is expected to clinch at the world's 24th place for the global purchasing power parity (PPP), up from 27th spot last year, with a projected gross domestic product (GDP) of USD1.5 trillion (RM6.7 trillion) by 2050 (New Straits Times, 2017). Thus, signalling that Malaysia is on the right track enjoying the rapid growth with continuous supports from the Government (Fong, 2017; New Straits Times, 2017). Therefore, it is timely for Malaysia to focus on sustaining and strengthen its domestic economic players namely SMEs, local commodities producers such as palm oil and rubber as well as other manufacturers as it has evidently continued to support GDP growth in the previous years (Alias, 2017; Mahbob, 2017). Malaysian SMEs should continue to implement their business strategies in capturing more local consumers. On the other hand, they should also looking for the largest market outside Malaysia in order to sustain, survive and grow themselves regardless of the world's economic uncertainty.

\subsection{Further Discussion and Mitigation}

Shum (2017) stated that, the remaining members of TPP were seeking to move forward and ways to salvage the agreement after the US left the pact. Australia, Malaysia and New Zealand showed interest and enthusiasm to continue with an 11-member partnership as well as the possibility to discuss the next action including the amendment to the TPP's clauses (Bernama, 2017; Jaipragas, 
2017). The members were hoping for the best that TPP11 survive the challenging time into reality as they spent almost a decade to negotiate with the pact (Abidin, 2017; Rana \& Ji, 2017). They agreed to proceed with the pact and amend the 19 laws which were stated in the TPP particularly issue related to labour (Damodaran, 2017). The remaining 11 members will hold a meeting to discuss the next step of progression of the deal particularly on the amendment of the clauses (Bernama, 2017). Datuk Seri Mustapa Mohamed, also mentioned that the detailed discussion about TPP will take place at the Asia-Pacific Economic Cooperation (APEC) in Vietnam (Chow \& Ooi, 2017).

The current TPP agreement should be altered accordingly by the TPP11's members in order for the smooth and efficient implementation and should reconsider if the US rejoining the agreement in the future because the US has more to lose from leaving the pact as the US economy has an economic relationship with TPP countries since 1980s (Rana \& Ji, 2017). Furthermore, Rana and $\mathrm{Ji}$ (2017) also suggested that the government agencies and business association in TPP11 countries, should assist the domestic firms particularly SMEs in terms of information dissemination, training and technical consultations for the fully optimisation the negotiated agreements. Other possibility option including entering bilateral free-trade agreement (FTA) with other members of TPPA in order to mitigate the outcome of the US withdrawal from the agreement (Bernama, 2017). According to Rana and Ji (2017), the net benefit of TPP11 among all its members are 0.4 per cent from their combined GDP and adds some USD5 billion to global welfare. Malaysia's participation in the TPP would allow a continuously playing its crucial role in the process of economic integration particularly in the Asia Pacific region (Bernama, 2017).

\subsection{Co-operation with Other Countries}

Based from Moody's Investors Service, the withdrawal of US from TPP connotes material loss for Malaysia and Vietnam as these countries will miss out on growth and export opportunities in terms of trade and large foreign direct investment (FDI) in flows with US over the long term period (Chua, 2017). Malaysia joined the TPPA with the objectives to gaining better access to market especially the US market (Bernama, 2017). In a similar vein, Chua (2017) also stated that the pull out also influence Malaysia's geopolitical relationship with the US since the number of bilateral visits by Obama and his administration's general pivot to Asia. However, Malaysia has a number of regional and bilateral trade deals signed or being negotiated including ASEAN Free Trade Agreement (AFTA) and bilateral free trade agreement with Japan in 2005, Pakistan (2007), New Zealand (2009), Chile (2010), India (2011), Australia (2012) and Turkey on 17 April 2014 (MITI, 2016; Moon, 2016). In addition, the East ASEAN Growth Area or BIMP-EAGA also provides golden opportunity for Malaysia to further expand their business to this region. Consequently, the failure of the TPP open another avenue for Malaysia to strengthening regional integration within Asia particularly the intra-regional exports via Asean as well as Asean trade partners (Cheah, 2017). At the same time, Malaysia was also actively negotiating with European Union (EU), Sri Lanka and Iran (Chow \& Ooi, 2017).

In addition, Malaysia also looks into working together strengthening economic integration within Asean members and to focus for the conclusion of the RCEP between Australia, China and New Zealand (Bernama, 2017; Edwards, 2017). The RCEP was proposed by the Association of Southeast Asian Nations (Asean) that focusing on regional economic integration and trade liberalisation (Wang, 2016; Zhang, 2016). RCEP is a more Asia-centric trade deal with 16 participating countries including Asean, Australia, China, India, Japan, New Zealand and South Korea with aim to strengthen trade ties between participating members (Figure 1) (Cheah, 2017; Wang, 2016). In addition, Wang (2016) also stated that the pact will leads into the world's largest free trade area with 3.5 billion in population and a combined GDP of USD23 trillion (one-third of the world's total). Previously, China has proposed a trade group called the Free Trade Area of the Asia Pacific (FTAAP) and supported the Southeast Asian-backed RCEP as an alternative trade agreements to TPP (Lynn, 2017). RCEP contributes USD23 trillion of market size or 30 per cent of global gross domestic products (GDP) compared to the TPP with USD28.5 trillion or 40 per cent of world GDP (Cheah, 2017). The pact creates opportunity for Malaysia in terms of trade similarities 
especially from the Asian region to penetrate its market. Moreover, RCEP help Malaysia to facilitate inflow of investments from China into Malaysia as well as checking dumping of products from China on other markets (Bernama, 2017). In fact, Malaysia has already a FTA with China.

\subsection{Market Opportunity with the Digital Free Trade Zone (DFTZ)}

Malaysia launched the world first Digital Free Trade Zone (DFTZ) with aimed to improve the international e-commerce as well as Internet-based innovations in order to catalyse nation's digital economy (Idris, 2017; Sim, 2017). The trade zone was initiated between Malaysian Government and Jack Ma of Alibaba Group, China (Tangau, 2017). The DFTZ related to Industry 4.0 which regards on the Internet usage in automation and exchange data in manufacturing technology in conjunction with Malaysia Internet Economy Year 2017 (Bernama, 2017). The trade zone would provide physical and virtual zones to enable SMEs to grab the opportunity on the emerging growth of the Internet economy and cross border e-commerce activities (Tangau, 2017; Zakariah \& Ismail, 2017). According to Yeoh (2017), the DFTZ would also enhanced the Malaysian SMEs in terms of export capabilities in the digital market.

DFTZ also creates an opportunity for SMEs as an alternative channels of sales and directly sell their products and services to customers (Yeoh, 2017). Moreover, DFTZ also become the platform and startups for SMEs to innovate in the area of e-commerce (Tan, 2017). In addition, DFTZ was viewed as a unique logistic hub that will bring together SMEs, micro businesses, customs clearance, warehousing and fulfilment facilities in one place in order to increase trade with Asean as well as the world (Ho \& Sim, 2017; Liow, 2017). In addition, DFTZ will assist SMEs and micro enterprises to export their products globally easily and allow global marketplaces to outsource products from local manufacturers (Ho, 2017). Therefore, SMEs are no longer competing or focus solely on domestic market but also going on the global scale particularly to China (Rosli, 2017).

The birth of DFTZ comes from the initiative of the National E-commerce Strategic Roadmap intended to double the Malaysia's e-commerce growth from 10.8 per cent to 20.8 per cent and increase the GDP contribution to RM211 billion by 2020 (NST Team, 2017). The establishment of DFTZ as an e-commerce hub is a co-operation between the Alibaba Group and the Malaysia Digital Economy Corporation (MDEC) (Tan, 2017). Kuala Lumpur Internet City (KLIC) is expected to become the main digital hub of the DFTZ and become an epicentre of Southeast Asia's Internet economy which house at least 1,000 companies as well as 25,000 tech professionals with an estimated gross development value (GDV) of RM5 billion (Ho \& Sim, 2017; McSpadden, 2017). The first phase of the DFTZ also includes developing a regional e-commerce and logistics hub near the Kuala Lumpur International Airport (KLIA) (Naidu, 2017). DFTZ is expected to contribute to the growth rate of Malaysian SMEs' goods export and 60,000 direct as well as indirect job employments for Malaysian by 2025 with estimated USD65 billion worth of goods moving through this trade zone (Ee, 2017; Ho, 2017). In addition, Malaysian SMEs can leverage their existing strengths especially the halal products as well as electrical and electronic products into DFTZ for the global market (Chua, 2017).

\section{Conclusions}

The TPP provides the best foundation for local SMEs to spur their growth through greater market access and to stimulate the enhancement of products and services. In addition, the deal also create a healthy competition for domestic and international market through trade liberalisation. The deal would have increased local exports especially related to oil and gas as well as palm oil. Now, it is a time for Malaysian SMEs to move out from their comfort zone especially Bumiputera-owned SMEs (the indigenous-owned SMEs). They need to be more proactive in implementing their business strategies accordingly in the midst of facing not only TPP but other FTA as well. SMEs should promote an environment that supports customer-centric manufacturing by co-create with their customers, suppliers and partners in order to remain updated with new and specific knowledge for the innovation as well as possible solution towards products and services. This collaboration in turn 
help them to stay competitive, relevant to the market and to sustain their business livelihood facing the trade liberalisation. The US withdrawal from the pact creates uncertain situation for TPP but the remaining countries are looking forward to salvage the deal with the amendment on the current clauses as they will meet to discuss the next steps regarding the issue. Malaysia, has prepared the contingency plans by focusing on regional economic integration if the TPPA fail into its materialisation. The regional economic integration including AEC, the Brunei Darussalam, Indonesia, Malaysia and the Philippines-East ASEAN Growth Area (BIMP-EAGA), FTA with BRICS (Brazil, Russia, India, China and South Africa), Europe, RCEP and bilateral FTAs with other TPPA members that currently do not have any preferential trading with Malaysia. DFTZ open another avenue for local SMEs to take advantage of the emerging of Internet and digital market with the fully support from the Government. Malaysian SMEs should become more versatile, adaptable and resilient to any changes surrounding them. In a nutshell, Malaysian SMEs should stay away from their comfort zone and start to get sweats!

\section{Acknowledgements}

This is part of the PhD research work on SMEs in Malaysia, conducted at School of Management, Universiti Sains (USM) Malaysia and was supported by the Ministry of Higher Education Malaysia and Universiti Malaysia Sabah (UMS).

\section{References}

Abidin, I. S. Z. (2017, February 12). Don't let TPP die. New Sunday Times, p. 23.

Agencies. (2016, December 10). Japan's upper house approves TPP. New Straits Times, p. B7.

Al Jazeera. (2017, January 24). Trump withdraws US from Trans-Pacific Partnership deal: President formally pulls US out of massive 12-nation TPP trade deal that covers 40 percent of world's economy. Al Jazeera. Retrieved from http://www.aljazeera.com/news/2017/01/trump-withdraws-trans-pacific-partnership-tppdeal-170123170334145.html on 25 January 2017

Alias, N. Z. (2017). Trump and the Malaysian economy. The Edge Malaysia, 1152, 52.

Asian Development Bank. (2015). Asia SME finance monitor 2014. Asian Development Bank. Retrieved from http://www.adb.org/sites/default/files/publication/173205/asia-sme-finance-monitor2014.pdf on 23 January 2017

Baker, P. (2017, January 23). Trump abandons Trans-Pacific Partnership, Obama's Signature trade deal. The New York Times. Retrieved from https://www.nytimes.com/2017/01/23/us/politics/tpp-trump-tradenafta.html? r=0 on 25 January 2017

Bernama. (2017, March 20). Alibaba's Jack Ma to attend Digital Free-Trade Zone launch on Wednesday. Malay Mail Online. Retrieved from http://www.themalaymailonline.com/malaysia/article/alibabas-jack-ma-toattend-digital-free-trade-zone-launch-on-wednesday on 23 March 2017

Bernama. (2017, January 23). Malaysia, 10 other TPPA members to discuss next course of action. The Star Online. Retrieved from http://www.thestar.com.my/business/business-news/2017/01/23/malaysia-and-10other-tppa-members-to-discuss-next-course-of-action/ on 26 January 2017

Bernama. (2017, March 14). Malaysia in no hurry to bury the TPP. Daily Express, p. 19.

Bernama. (2017, January 22). Malaysia's move if TPPA falls through. The Star Online. Retrieved from http://www.thestar.com.my/news/nation/2017/01/22/malaysias-move-if-tppa-falls-through-mustapa-wewill-look-into-pursuing-bilateral-ftas-with-members/ on 26 January 2017

Bernama. (2017, March 14). Mustapa: M'sia less interested in TPPA with US withdrawal. Daily Express, p. 19.

Bernama. (2017, February 28). TPPA: Do we hang on or move on? New Sabah Times, p. 10.

Bernama. (2017, February 27). TPPA: Do we hang on or move on? Borneo Post Online. Retrieved from http://www.theborneopost.com/2017/02/27/tppa-do-we-hang-on-or-move-on/ on 12 March 2017

Bernama. (2017, January 24). US withdrawal from TPP affects palm oil export target, says Mah. The Star Online. Retrieved from http://www.thestar.com.my/business/business-news/2017/01/24/us-withdrawalfrom-tpp-affects-palm-oil-export-target-says-mah/ on 30 January 2017.

Bhattacharjee, R. B. (2017). Post-TPP, it is time to frame a humane growth model. The Edge Malaysia, 1148, 44.

Bradner, E. (2017, January 23). Trump's TPP withdrawal: 5 things to know. CNN. Retrieved from http://edition.cnn.com/2017/01/23/politics/trump-tpp-things-to-know/ on 25 January 2017 
Central Department of Small and Medium Enterprises Development. (2015). Number of registered enterprises in states and regions up to February, 2015. Retrieved from http://www.smedevelopmentcenter.gov.mm/ on 22 January 2017

Cheah, C. S. (2017). How to navigate Trumponomics and Brexit/Frexit. Focus Malaysia, 222, 38.

Chow, M. D. \& Ooi, T. C. (2017, March 14). Malaysia less keen on TPP. New Straits Times, p. 28.

Chua, S. A. (2017). Alibaba a clear winner from Malaysia's Digital Free Trade Zone. The Edge Malaysia, 1155, 68-69.

Chua, S. A. (2017). Where Malaysia is vulnerable to Trumponomics. The Edge Malaysia, 1148, 7-8.

Dali, R. (2016, October 21). Government declares 2017 as Startup and SME Promotion Year. Astro Awani. Retrieved from http://english.astroawani.com/malaysia-news/government-declares-2017-startup-and-smepromotion-year-120130 on 12 January 2017

Damodaran, R. (2017, February 9). Modest growth likely for imports, exports. New Straits Times, B3.

Diamond, J. \& Bash, D. (2017, January 24).Trump signs order withdrawing from TPP, reinstate 'Mexico City policy' on abortion. CNN. Retrieved from http://edition.cnn.com/2017/01/23/politics/trans-pacificpartnership-trade-deal-withdrawal-trumps-first-executive-action-monday-sources-say/ on 25 January 2017

Edwards, J. (2017, January 26). What's next after the US withdrawal from the TPP? The Pacific countries will continue negotiating regional economic arrangements without the US. Al Jazeera. Retrieved from http://www.aljazeera.com/indepth/opinion/2017/01/withdrawal-tpp-170126092759229.html on 28 January 2017

Ee, A. N. (2017, March 22). Digital Free Trade Zone launched. The Sun Daily. Retrieved from http://www.thesundaily.my/news/2202767 on 23 March 2017

Fong, F. (2017, March 18). 63pc growth in FDI reflects investor confidence. New Straits Times, p. 11.

Garcia, F. (2017, January 24). President Donald Trump scraps TPP trade deal by executive order. Independent. Retrieved from http://www.independent.co.uk/news/world/americas/donald-trump-tpp-scraps-trade-dealexecutive-order-signs-us-president-white-house-day-one-a7542211.html on 28 January 2017

Greenfield, C. \& White, S. (2017, January 24). Trans-Pacific Partnership nations look to salvage deal after Donald Trump pulls out. Live Mint. Retrieved from http://www.livemint.com/Politics/gupUqEySfhpkrk5XzOK0DL/TransPacific-Partnership-nations-look-tosalvage-deal-after.html on 11 March 2017

Harun, K. A. (2017, January 28). What's there without TPP? New Straits Times. Retrieved from http://www.nst.com.my/news/2017/01/207879/whats-there-without-tpp on 28 February 2017

Hashim, M. K. \& Ahmad, S. (2006). Moderating effect of technology on the business strategy - performance relationship in Malaysian SMEs. In M. K. Hashim (Ed.), Strategic issues in Malaysian small and mediumsized enterprises (87-104). Sintok, Kedah: Universiti Utara Malaysia Press.

Ho, W. F. (2017, March 26). Push for digitising M'sia. Sunday Star, p. 23-24.

Ho, W. F. \& Sim, L. L. (2017, March 23). Paving the way to mega trade growth. The Star, p. 2.

Idris, A. N. (2017, March 21). Digital Free Trade Zone to be launched tomorrow - Miti. The Edge Malaysia. Retrieved from http://www.theedgemarkets.com/my/article/digital-free-trade-zone-be-launched-tomorrow\%E2\%80\%94-miti on 23 March 2017

Jaipragas, B. (2017, January 24). Can the Trans-Pacific Partnership be salvaged? Forget Trump - Malaysia, Australia, New Zealand think so. South China Morning Post. Retrieved from http://www.scmp.com/weekasia/geopolitics/article/2065021/trans-pacific-partnership-salvageable-forget-trump-malaysia on 10 February 2017

John, B. (2017, March 10). M'sia should pursue TPPA realisation: UMS professor. New Straits Times. Retrieved from http://www.nst.com.my/news/2017/03/219467/msia-should-pursue-tppa-realisation-ums-professor on 15 March 2017

Jozuka, E. (2017, January 26). TPP vs RCEP? Trade deals explained. CNN. Retrieved from http://edition.cnn.com/2017/01/24/asia/tpp-rcep-nafta-explained/ on 1 February 2017

Kana, G. (2017, March 17). Malaysia consumer spending seen recovering. The Star Online. Retrieved from http://www.thestar.com.my/business/business-news/2017/03/17/gradual-recovery-in-consumer-spendingseen-in-second-half/ on 20 March 2017

Kang, M. (2016, November 21). Reflections on Budget 2017. The Star Online. Retrieved from http://www.thestar.com.my/metro/smebiz/columns/2016/11/21/reflections-on-budget-2017/ on 12 January 2017

Kok, C. (2017, January 7). Growing optimism for the ringgit to strengthen in the second half. The Star. Retrieved from https://www.pressreader.com/malaysia/the-star-malaysia-starbiz/20170107/281784218772946 on 25 February 2017

Lasuin, C. A., Omar, A. \& Ramayah, T. (2016). The advantages of trans-pacific partnership agreement (TPPA) on Malaysian small, medium enterprises (SMEs). Journal of Advanced Research in Business and Management Studies, 5(1), 35-46. $\quad$ Retrieved from http://www.akademiabaru.com/doc/ARBMSV5_N1_P35_46.pdf on 26 February 2017 
Liow, T. L. (2017, April 7). We either grow or be left behind. The Star, p. 24.

Lynn, B. (2017, January 24). TPP nations seek to save trade deal after US withdraws. Retrieved from http://learningenglish.voanews.com/a/tpp-nations-seek-to-save-trade-agreement-after-uswithdraws/3690246.html 8 February 2017

Mahbob, S. (2017, February 9). Time to focus on sustaining domestic demand. New Straits Times, p. B6.

McSpadden, K. (2017, March 22). Malaysia officially launches digital free trade zone, Catcha Group will be building the digital hub. e27. Retrieved from https://e27.co/malaysia-launches-digital-free-trade-zone-willcatcha-group-building-hub-20170322/ on 23 March 2017

Mgeni, T. O. (2015). Impact of entrepreneurial leadership style on business performance of SMEs in Tanzania. Entrepreneurship \& Organization Management, 4(2), 1-9. doi:10.4172/2169-026X.1000142

MITI. (2016). TPPA-Perjanjian Perkongsian Trans-Pasifik: Jawapan kepada kebimbangan, salah faham dan tuduhan. Kuala Lumpur, Malaysia: Kementerian Perdagangan Antarabangsa \& Industri Malaysia.

Moon, H. (2016, December 2). No small matter. China Daily Asia. Retrieved from http://www.chinadailyasia.com/asiaweekly/2016-12/02/content_15535807.html on 26 January 2017

Mutandwa, E., Taremwa, N. K. \& Tubanambazi, T. (2015). Determinants of business performance of small and medium size enterprises in Rwanda. Journal of Developmental Entrepreneurship, 20(1), 1-12. doi:10.1142/S1084946715500016

Naidu, S. (2017, March 22). Alibaba to set up logistics hub in Malaysia's new digital free trade zone. Channel News Asia. Retrieved from http://www.channelnewsasia.com/news/business/alibaba-to-set-up-logisticshub-in-malaysia-s-new-digital-free/3616222.html on 23 March 2017

New Straits Times. (2017, February 11). Asia to dominate markets by 2050. New Straits Times, p. 6.

New Straits Times. (2017, March 9). Country enjoying rapid growth. New Straits Times, p. 19.

Nguyen, H. V. (2017, January 18). TPP's demise sounds no death knell. The Star, p. 20.

Northam, J. (2016, November 11). Obama isn't expected to push Congress on Trans-Pacific Partnership trade deal. NPR. Retrieved from http://www.npr.org/sections/thetwo-way/2016/11/11/501778485/obama-notexpected-to-push-congress-on-trans-pacific-partnership-trade-deal on 13 January 2017

NST Team. (2017, March 22). Najib, Jack Ma to launch world's first Digital Free Trade Zone today. News Straits Times. Retrieved from http://www.nst.com.my/news/2017/03/223252/najib-jack-ma-launch-worlds-firstdigital-free-trade-zone-today on 23 March 2017

Olorunnipa, T., Pettypiece, S. \& Townsend, M. (2017, January 24). Trump Revamps U.S. Trade Focus by Pulling Out of Pacific Deal. Bloomberg. Retrieved from https://www.bloomberg.com/politics/articles/201701-23/trump-said-to-sign-executive-order-on-trans-pacific-pact-monday on 26 January 2017

Palit, A. (2017, January 26). Can the Trans Pacific Partnership survive after Trump? The Conversation. Retrieved from https://theconversation.com/can-the-trans-pacific-partnership-survive-after-trump-71821 on 27 January 2017

Petrosyan, R., Gandall, K., Columbus, T., Stern, M., Kazand, A., Shores, K. \& Haney, A. (2017, January 31). Why we still need a Trans-Pacific Partnership. The Millennial Review. Retrieved from http://www.themilreview.com/fiscal-policy/why-we-still-need-a-trans-pacific-partnership on 20 February 2017

Pooi, K. C. (2017, February 16). Strong consumer spending spurs Malaysia's growth to 1-year high. Bloomberg. Retrieved from https://www.bloomberg.com/news/articles/2017-02-16/malaysia-s-gdp-growth-beatsestimates-on-household-spending on 20 March 2017

Rana, P. B. \& Ji, X. (2017). TPP12 vs TPP11: Gainers and losers. Focus Malaysia, 221, 38.

Rosli, L. (2017, March 30). SME Bank expects to boost fund allocation for online businesses. New Straits Times, p. B5.

Rosli, L. (2017, March 18). SME Bank sees loan growth at 7pc. New Straits Times, p. B2.

Savransky, R. (2017, January 23).Trump to sign executive order to withdraw from TPP. The Hill. Retrieved from http://thehill.com/business-a-lobbying/315598-trump-to-sign-executive-order-on-plan-to-withdraw-from-tpp on 25 January 2017

Selva, M. T. \& Emily, K. (2017, January 19). Malaysian SMEs awarded for their accomplishments at SOBA 2016. The Star Online. Retrieved from http://www.thestar.com.my/metro/focus/2017/01/19/hats-off-tooutstanding-businesses-malaysian-smes-awarded-for-their-accomplishments-at-soba-2016/ 26 February 2017

Shum, D. (2017, January 24). TPP members look to salvage Pacific Rim trade deal after U.S. withdrawal. Global News. Retrieved from http://globalnews.ca/news/3201363/tpp-members-look-to-salvage-pacificrim-trade-deal-after-u-s-withdrawal/ on 5 February 2017

Sim, L. L. (2017, March 22). Najib: Malaysia's Digital Free Trade Zone is a world's first. The Star Online. Retrieved from http://www.thestar.com.my/news/nation/2017/03/22/najib-malaysias-digital-free-tradezone-is-a-worlds-first/ on 23 March 2017

SME Annual Report 2014/15. (2015). Key statistics on SMEs. Retrieved from http://www.smecorp.gov.my/vn2/sites/default/files/Appendices_1.pdf on 10 December 2016 
SME Bank. (2017). SME definition by BNM. Retrieved from http://www.smebank.com.my/corporate-info/smedefinition/ on 23 March 2017

Smith, D. (2017, January 23). Trump withdraws from Trans-Pacific Partnership amid flurry of orders. The Guardian. Retrieved from https://www.theguardian.com/us-news/2017/jan/23/donald-trump-first-orderstrans-pacific-partnership-tpp on 26 January 2017

Suntivong, D. (2014). Make or break it in SMEs brand building, an empirical study of the impact of brand development on the performance of Thai SMEs. Journal of Business and Management, 16(4), 19-28. doi: $10.9790 / 487 X-16461928$

Tan, K. H. (2017, March 22). PM launches the Digital Free Trade Zone. The Star Online. Retrieved from http://www.thestar.com.my/tech/tech-news/2017/03/22/mdec-and-alibaba-launch-the-dftz/ on 23 March 2017

Tangau, M. (2017, April 2). M'sia now a step forward in the digital realm. Daily Express, p. 19.

The Brand Laureate. (2017). SMEs: Growing the economy. The Brand Laureate, 40, 48-50.

The Star Online. (2017, March 20). Growing with local demand. The Star Online. Retrieved from http://www.thestar.com.my/metro/smebiz/focus/2017/03/20/growing-with-local-demand/ on 27 February 2017

Walters, L. (2017, January 24). Small countries getting better deal in TPP - Trump spokesman. Stuff. Retrieved from http://www.stuff.co.nz/business/world/88700875/small-countries-getting-better-deal-in-tpp--trumpspokesman on 28 January 2017

Wang, H. (2016, December 22). Inclusiveness at heart of RCEP. China Daily, p. 19.

Yeoh, S. H. (2017, March 31). Shot in the arms for SMEs. The Star, p. 58.

Zakariah, Z. \& Ismail, L. (2017, March 22). Jack Ma: Digital Free Trade Zone proof govts and businesses can work together. New Straits Times. Retrieved from http://www.nst.com.my/news/2017/03/223395/jack-madigital-free-trade-zone-proof-govts-and-businesses-can-work-together on 23 March 2017

Zhang, E. (2016, December 8). Prepare to counter effects of Trumponomics, China Daily, p. 11.

Zulfakar, M. (2016, November 25). TPP partners wait for 'greater clarity'. The Star, p. 4. 